\title{
ANALISIS DAN PERANCANGAN SISTEM ADMINISTRASI PASANG BARU INDIHOME DI PT. TELKOM INDONESIA PLASA TANJUNGBALAI
}

\author{
Helmi Fauzi Siregar ${ }^{* 1}$, Nilfa Sari ${ }^{2}$ \\ Universitas Asahan; Jln. Jend. Ahmad Yani, telp/fax (0623)347222 \\ ${ }^{\left({ }^{1}, 2\right)}$ Jurusan Teknik Informatika, Fakultas Teknik UNA, Kisaran Sumatera Utara \\ e-mail: fauzi.helmi.hf@gmail.com, sarinilfa06@gmail.com
}

\begin{abstract}
Abstrak - Pada suatu instansi/perusahaan, juga ingin memiliki suatu perubahan yang dapat menunjang kemajuan perusahaannya. Dimana perubahan itu dapat membantu kerja karyawan supaya lebih cepat dan efektif. khususnya PT. Telkom Indonesia Plasa Tanjungbalai tentunya juga membutuhkan perubahan atas informasi untuk mengefisienkan dan mengefektifkan proses- proses administrasi yang ada di dalamnya. Pengelolaan dan pengolahan data yang dilakukan menggunakan sistem masih terlihat beberapa permasalahan yang ada pada sistem tersebut. Oleh karena itu, diperlukan perubahan sistem informasi yang mampu mengelola dan mengolah data secara efektif dan efisien sehingga terjadi komputerisasi data yang baik. Di dalam pelatihan ini akan menguraikan produk-produk yang dihasilkan pada masing-masing tahap analisis dan perancangan sistem administrasi pasang baru indihome di PT. Telkom Indonesia Plasa Tanjungbalai. Analisis dan perancangan sistem administrasi pasang baru indihome di PT. Telkom Indonesia Plasa Tanjungbalai dilakukan secara lengkap dan terperinci. Diharapkan dengan hasil kerja praktek ini dapat menjawab kesulitan yang seringkali dihadapi oleh customer sehingga bisa jauh lebih efisien dan efektif.
\end{abstract}

Kata kunci : Sistem Administrasi, Pengolahan data, Pasang baru Indihome

\begin{abstract}
In an agency/company, also want to have a change that can support the progress of his company. Where that change can help employees work more quickly and effectively. especially PT. Telkom Indonesia Plasa Tanjungbalai of course also requires changes to the information to streamline and streamline the administrative processes it. Management and data processing done using the system still looks some problems that exist on the system. Therefore, required changes in information systems capable of managing and processing data effectively and efficiently resulting in good computerized data. In this training will describe the products produced at each stage of analysis and new instal Indihome administration system at PT. Telkom Indonesia Plasa Tanjungbalai. Analysis and new instal of Indihome administration system at PT. Telkom Indonesia Plasa Tanjungbalai is complete and detailed. It is expected that with the results of this practical work can answer the difficulties that are often faced by the customer so that it can be much more efficient and effective.
\end{abstract}

Keywords: Administration System, Data processing, New Instal Indihome 


\section{PENDAHULUAN}

Seiring pesatnya perkembangan teknologi sistem informasi untuk memanfaatkan segala peluang yang memperoleh informasi menuntut adanya pengelolaan yang efektif dan efisien dalam proses administrasi di PT. Telkom Indonesia Plasa Tanjungbalai. Sistem administrasi merupakan suatu unsur yang penting dalam proses pelayanan dimana sistem tersebut akan mempengaruhi proses pelayanan nantinya. Ketika penulis melakukan kerja praktek di PT. Telkom Indonesia Plasa Tanjungbalai, penulis banyak melihat beberapa permasalahan yang ada pada sistem yang sedang berlangsung adalah cara membangun sistem administrasi pasang baru indihome di PT. Telkom Indonesia Plasa Tanjungbalai.

Berdasarkan pengalaman penulis tersebut, tampak adanya kerumitan dalam melakukan sistem administrasi pasang baru indihome di PT. Telkom Indonesia Plasa Tanjungbalai. Dimana kerumitan tersebut di alami oleh Customer Service dan Teknisi. Sebelumnya dalam sistem administrasi pasang baru indihome teknisi melakukan pengecekan lokasi pemasangan indihome. Sedangkan customer service melakukan pengecekan jumlah jaringan yang terpakai pada daerah pemasangan. Pada sistem yang akan diusulkan ini, customer service melakukan seluruh pengecekan, sedangkan teknisi menunggu konfirmasi pemasangan dari customer service.

Oleh karena itu, penulis mengambil kerja praktek yang berkaitan dengan teknologi informasi dengan judul penelitian "Sistem Administrasi Pasang Baru Indihome di PT. Telkom Indonesia Plasa Tanjungbalai “.

\section{TUJUAN}

Oleh sebab itu, perubahan sistem pada suatu perusahaan sangatlah penting. Karena dapat mempermudah kerja para karyawan dan untuk kemajuan suatu perusahaan. Jadi dengan adanya sistem administrasi pasang baru Indihome maka akan mempermudah kerja teknisi dalam melakukan pemasangan, dan membuat pelanggan tidak menunggu lama untuk konfirmasi pemasangan Indihome tersebut. Selain itu, Customer service juga tidak terbebani dengan keluhan pelanggan yang menanyakan kapan pemasangan akan dilakukan.

Tujuan Internal

Untuk membantu menyelesaikan permasalahan terkait sistem administrasi pasang baru Indihome pada PT. Telkom Indonesia Plasa Tanjungbalai.

Tujuan Eksternal

Bagi penulis

Untuk menambah wawasan dan pengalaman tentang situasi dan masalah yang di hadapi dalam dunia kerja terutama pada PT. Telkom Indonesia Plasa Tanjungbalai.

\section{Bagi pembaca}

Untuk memberitahu pembaca bagaimana sistem administrasi pasang baru Indihome yang digunakan dan dapat mengetahui apa saja yang diperlukan pada saat melakukan administrasi pasang baru Indihome di PT. Telkom Indonesia Plasa Tanjungbalai. 


\section{METODE PENELITIAN}

Teknik pengumpulan data yang dilakukan penulis adalah bertujuan untuk mengumpulkan berbagai informasi yang dibutuhkan untuk menyelesaikan penelitian terkait Sistem Administrasi Pasang Baru Indihome di PT. Telkom Indonesia Plasa Tanjungbalai.

1. Metode Pengamatan ( Observasi )

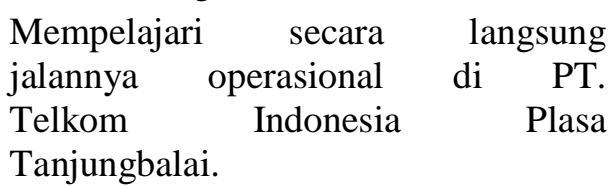

2. Metode Wawancara ( Interview )

Menanyakan secara langsung pada narasumber terkait Sistem Administrasi pasang baru Indihome di PT. Telkom Indonesia Plasa Tanjungbalai.

3. Studi Literatur

Mengumpulkan data dengan membaca dan mempelajari buku-buku atau mencari sumber lainnya yang berkaitan dengan objek yang di teliti di PT. Telkom Indonesia Plasa Tanjungbalai.

\section{HASIL DAN PEMBAHASAN}

\subsection{Analisis Sistem Berjalan}

Analisis sistem berjalan yaitu menganalisis sistem administrasi pasang baru indihome di PT. TELKOM INDONESIA Plasa Tanjungbalai.

IndiHome merupakan layanan

Triple Play dari Telkom yang terdiri dari Internet on Fiber atau high speed internet (internet cepat), phone (telepon rumah), dan interactive TV (UseeTV cable). Sehingga sehubungan dengan hal tersebut pelanggan baru yang ingin berlangganan mau tidak mau juga harus berlangganan telepon rumah beserta tv kabel Usee TV (satu paket).

Berikut ini adalah keunggulan dari layanan IndiHome yang diklaim sebagai layanan internet super cepat karena menggunakan fiber optik dari Telkom Indonesia, antara lain :

1. Internet Cepat

Fiber optik mampu mentransfer data (banwidth) hingga ratusan Mbps ( jauh lebih cepat dibandingkan kabel coax atau copper ).

2. Internet Stabil

Kecepatan fiber optik jauh lebih stabil dibandingkan coax atau copper pada saat dilakukan sharing (akses internet secara bersamaan).

3. Internet Handal

Fiber optik lebih tahan dalam kondisi cuaca apapun seperti serangan petir dan gangguan elektromagnet dibandingkan kabel coax atau copper, sehingga komputer anda menjadi lebih aman.

4. Internet Canggih

Fiber optik merupakan teknologi penghantar data tercanggih dan terbaru yang digunakan dalam layanan fixed broadband.

\subsubsection{Analisis Prosedur yang Berjalan}

Analisis prosedur yang berjalan yaitu kegiatan atau alur kerja dan dokumen dari suatu sistem.

\subsubsection{Flow Map}

Flow Map untuk sistem administrasi pasang baru indihome di PT. TELKOM INDONESIA Plasa Tanjungbalai 


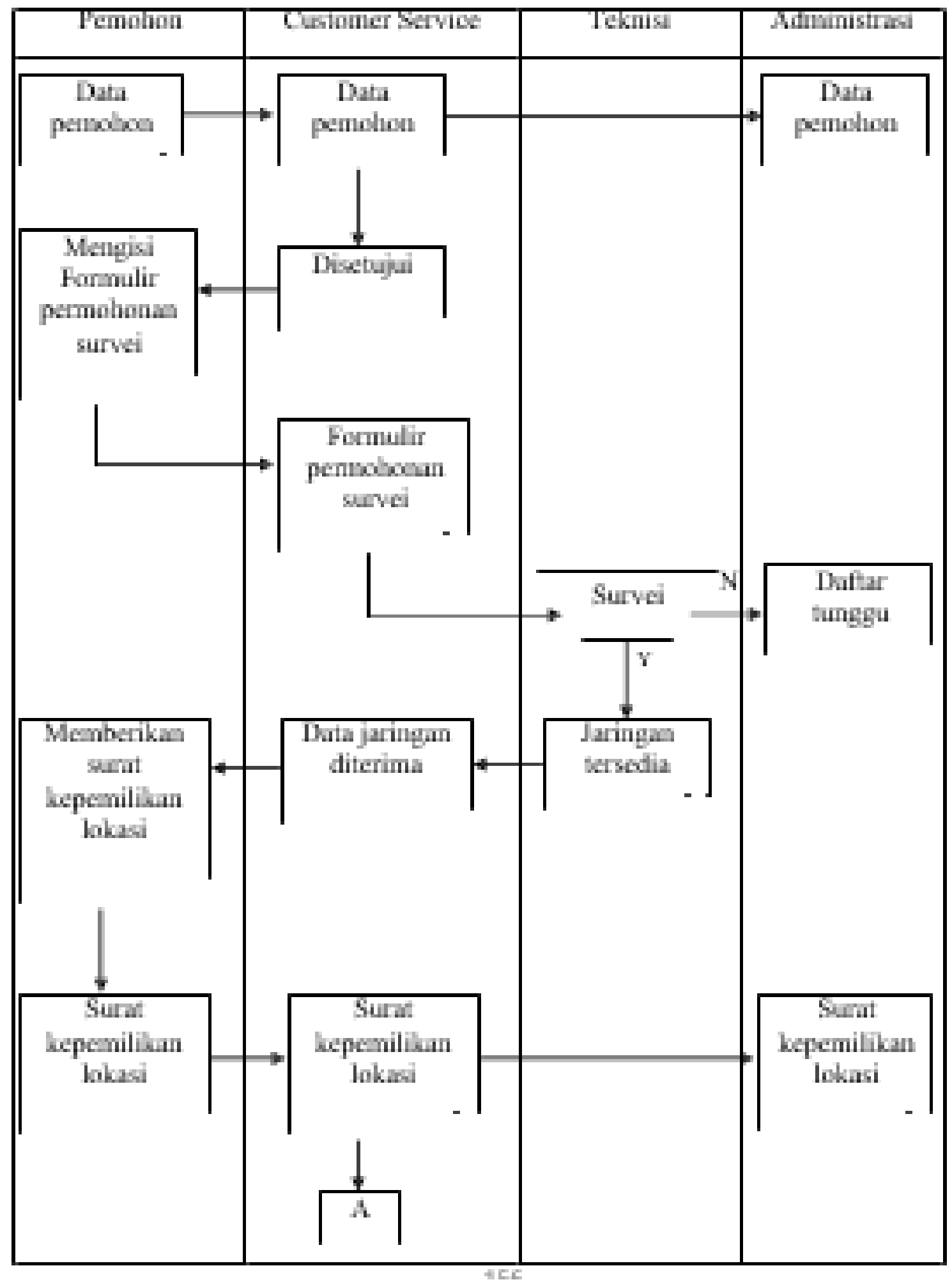




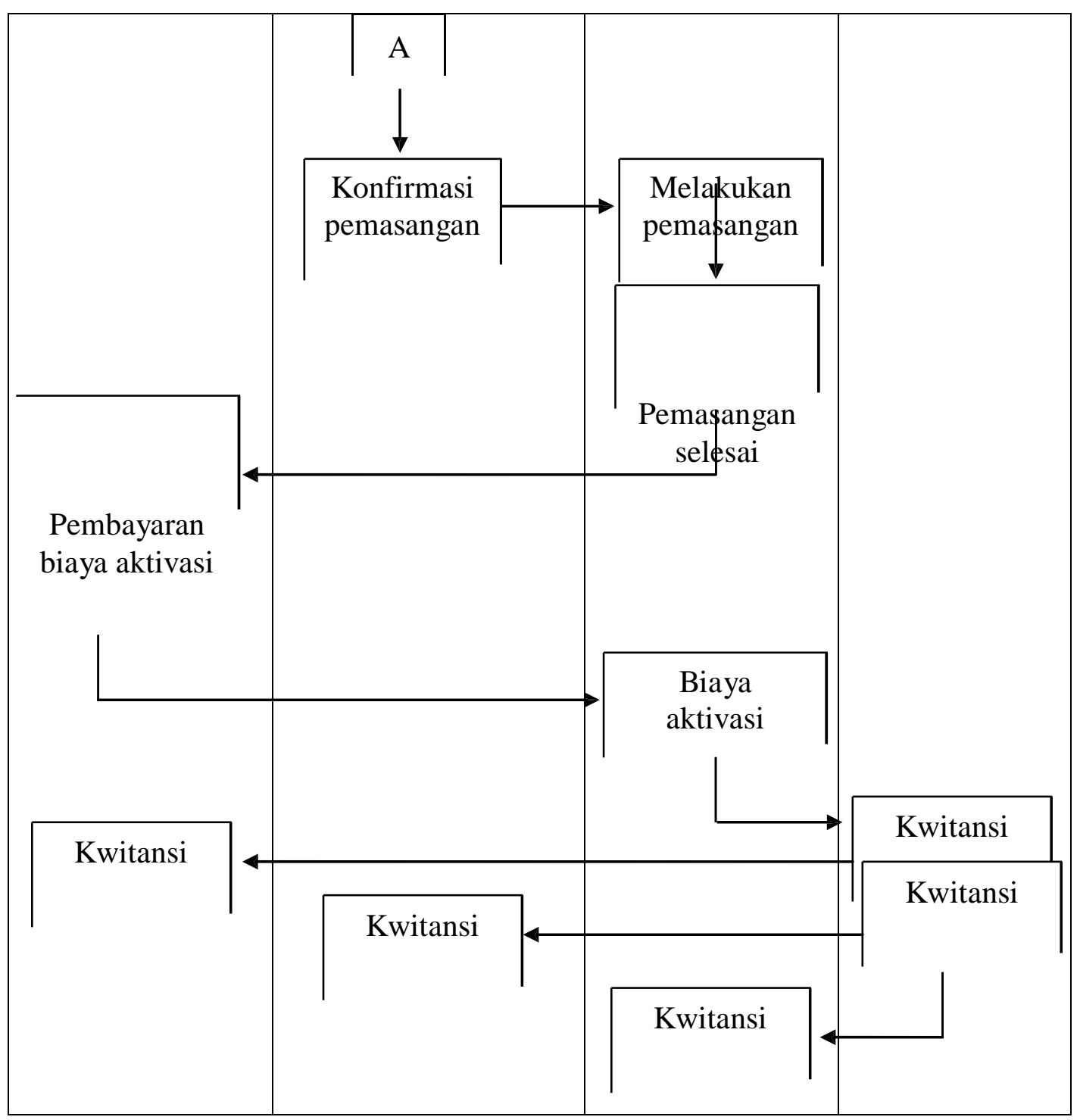

Gambar 4.1 Flow Map Sistem Administrasi Pasang Baru Indihome 
4.1.1.2

Diagram Konteks

Diagram konteks untuk Sistem

Administrasi Pasang Baru Indihome di
PT. TELKOM INDONESIA Plasa

Tanjungbalai.

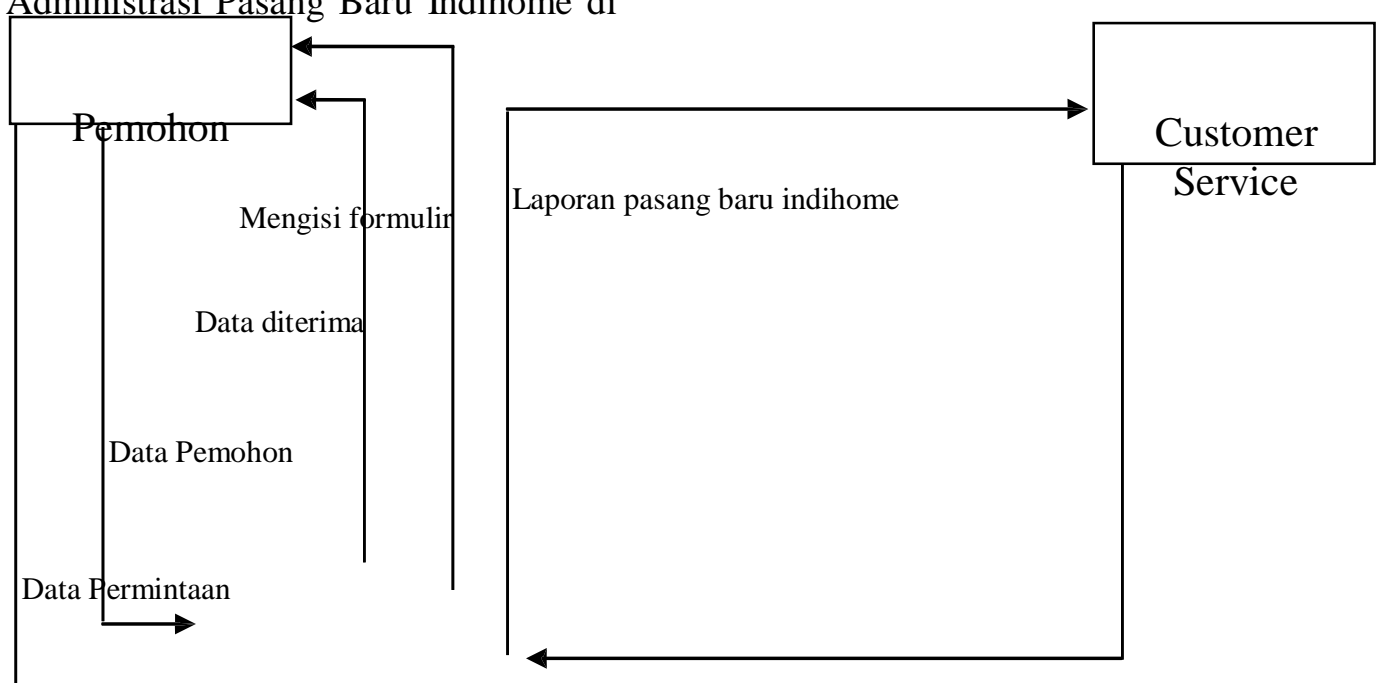

Sistem

Administrasi

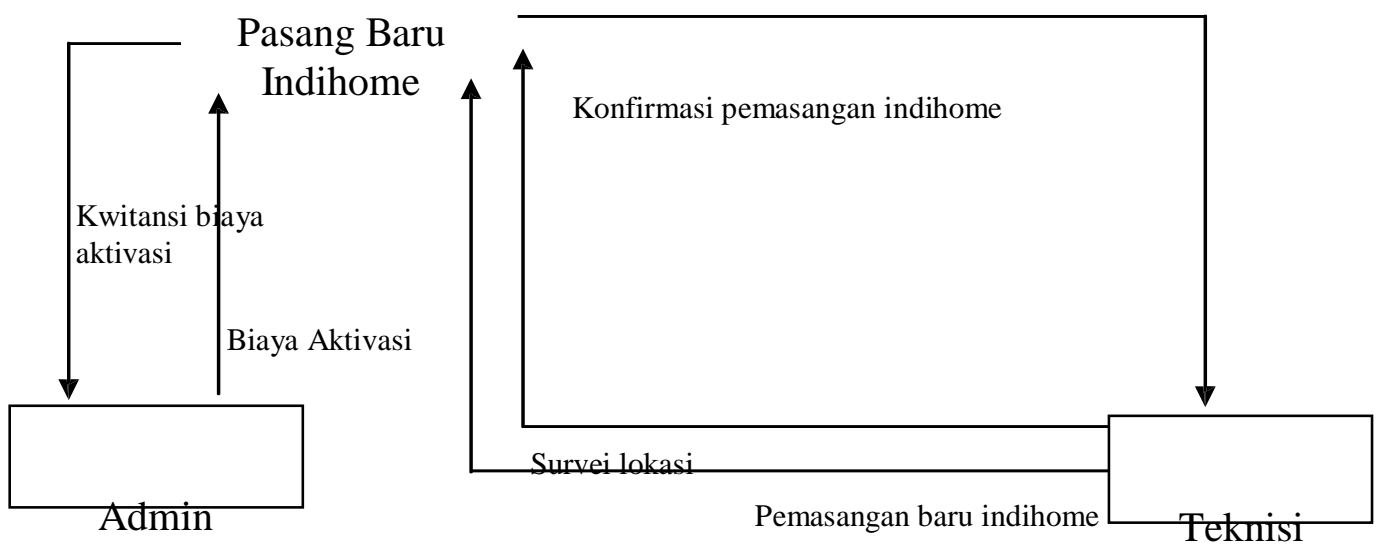

Gambar 4.2 Diagram Konteks Sistem Administrasi Pasang Baru Indihome 


\subsubsection{Data Flow Diagram Level 0} Data Flow Diagram Level 0 yang terdapat pada Sistem

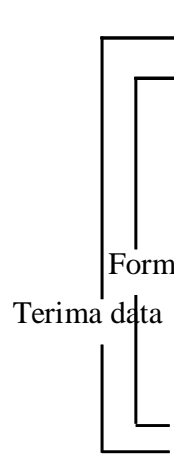

Pemohon

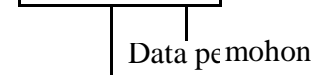

Data pe mintaan
Administrasi pasang baru indihome adalah sebagai berikut:

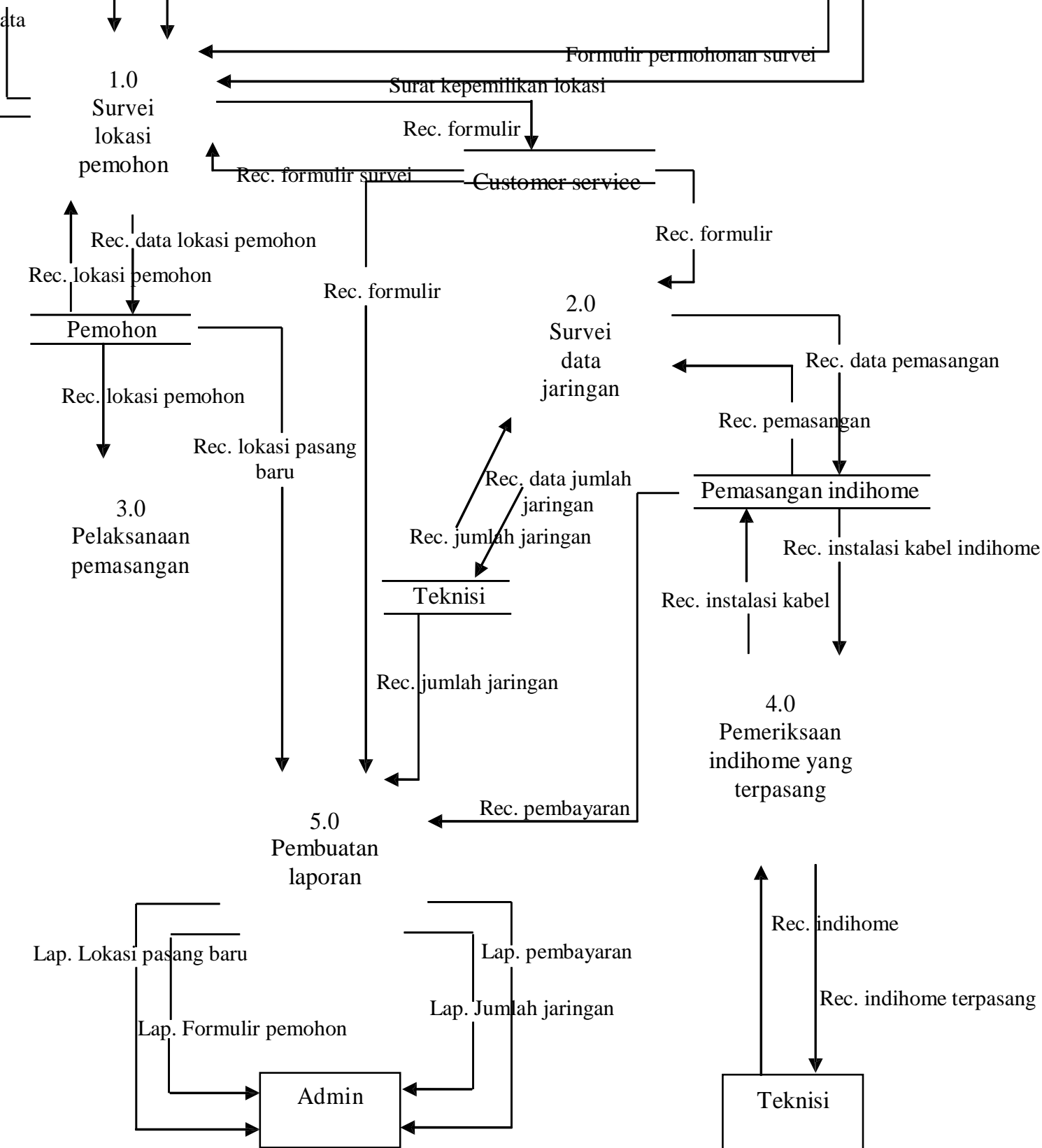

Gambar 4.3 Data Flow Diagram Level 0 Sistem Administrasi Pasang Baru Indihome 
4.2 Analisis Sistem Usulan

Analisis sistem usulan merupakan suatu kegiatan pengembangan prosedur dan proses yang sedang berjalan untuk menghasilkan suatu sistem yang baru atau memperbaharui sistem yang ada untuk meningkatkan efektifitas kerja agar dapat memenuhi hasil yang digunakan dengan tujuan memanfaatkan teknologi dan fasilitas yang tersedia. Analisis sistem usulan akan dilakukan pada sistem administrasi pasang baru Indihome di PT. Telkom Indonesia Plasa Tanjungbalai.

\subsubsection{Analisis Prosedur Sistem Usulan} Analisis prosedur bertujuan untuk memudahkan dalam pembuatan program dan memudahkan dalam menganalisa alir dokumen

\subsubsection{Flow Map Sistem Usulan}

Flow Map sistem usulan untuk sistem administrasi pasang baru Indihome di PT. Telkom Indonesia Plasa Tanjungbalai.

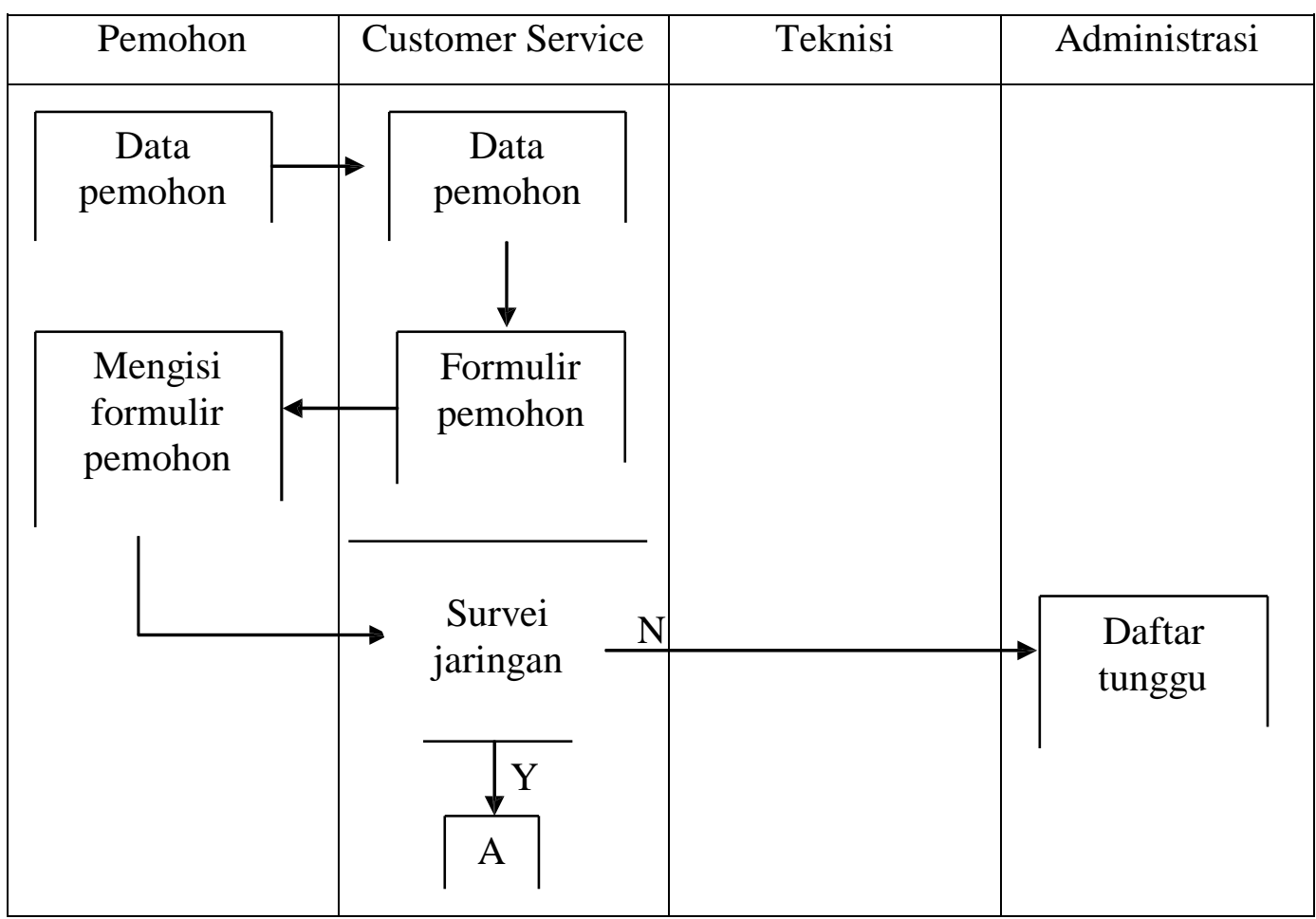




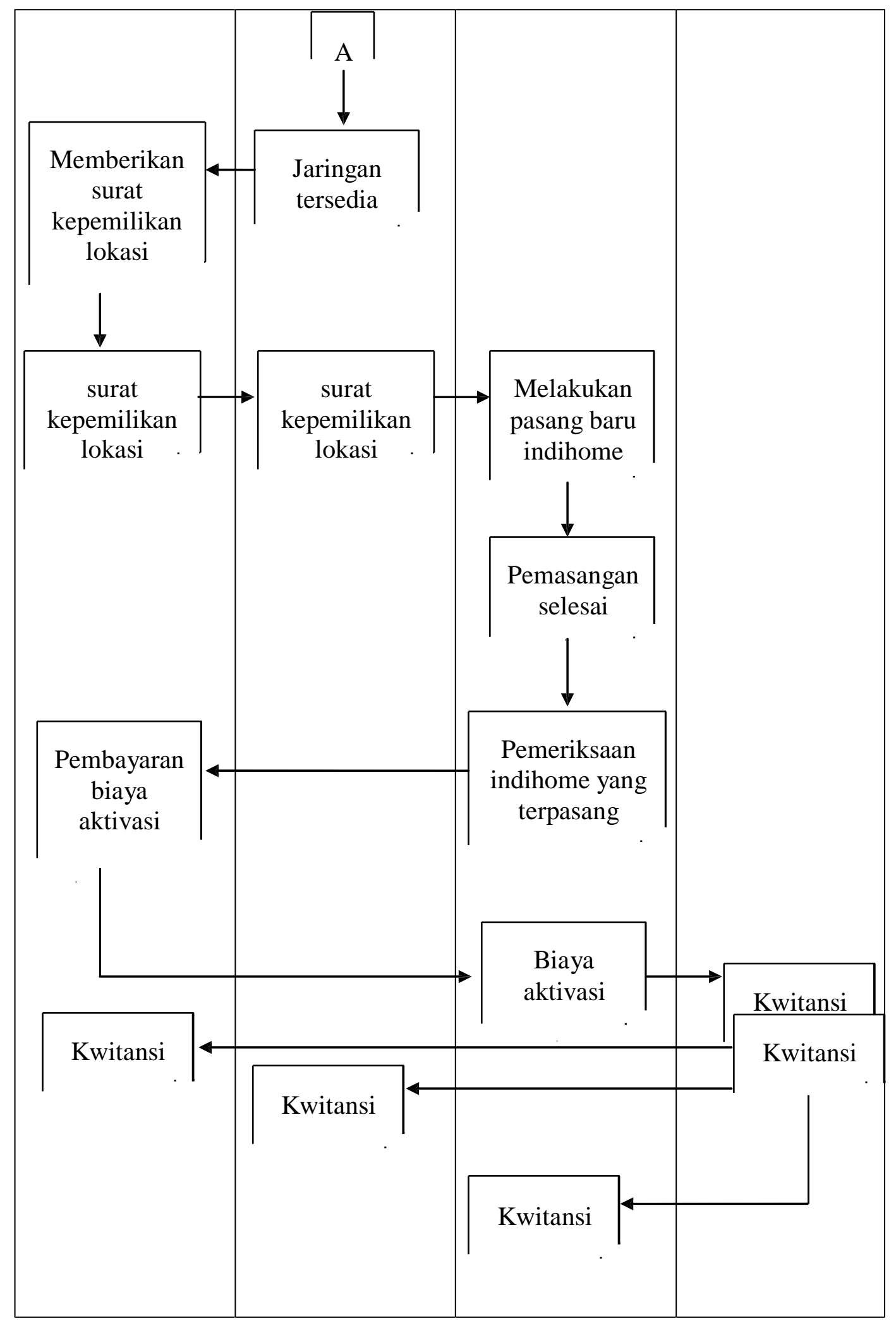

Gambar 4.4 Flow Map Sistem Yang Diusulkan Untuk Sistem Administrasi Pasang Baru Indihome 
4.2.1.2 Diagram Konteks Sistem Usulan

Diagram konteks sistem usulan

untuk sistem pasang baru indihome di
PT. TELKOM INDONESIA Plasa

Tanjungbalai.

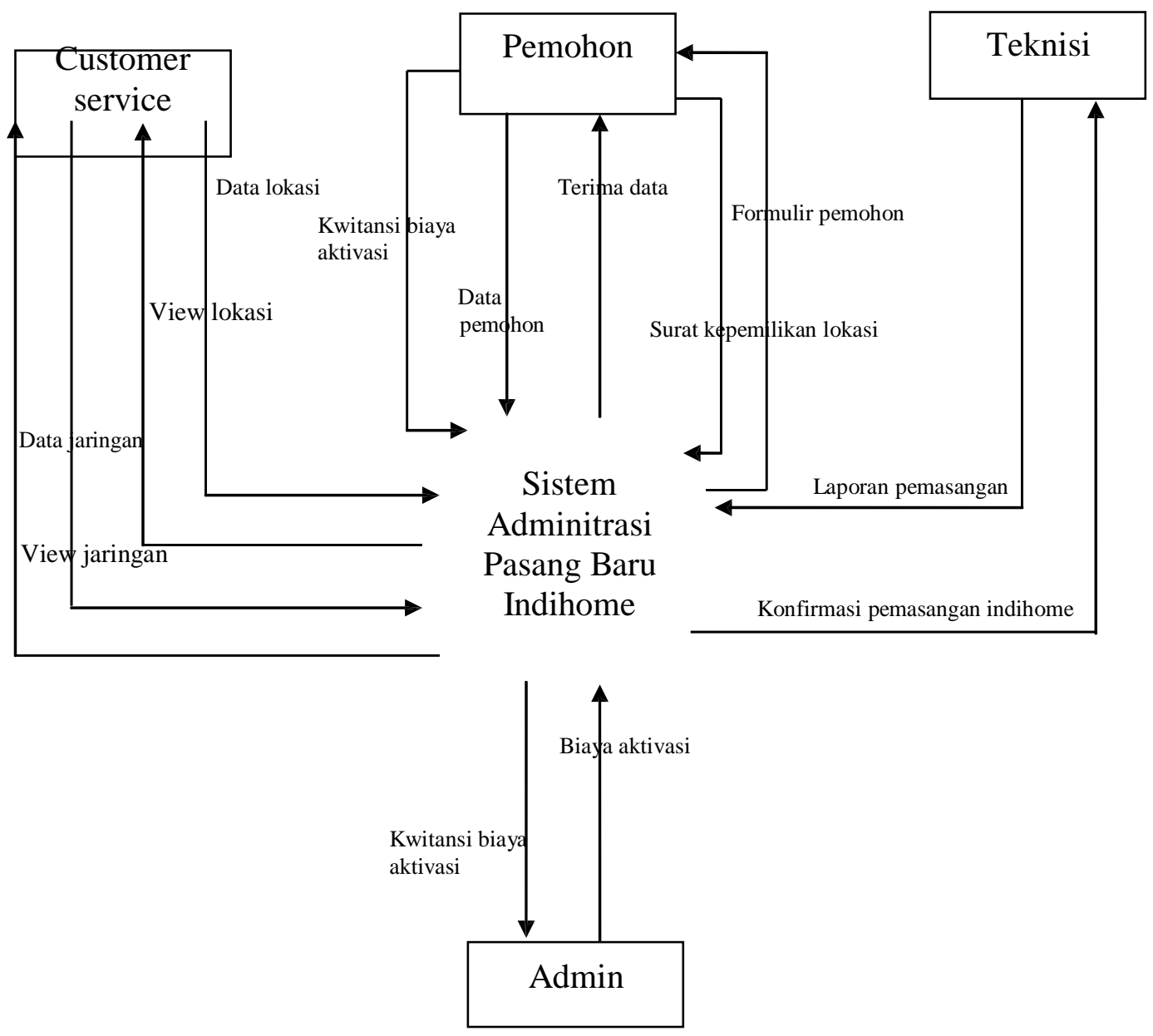

Gambar 4.5 Digram Konteks Sistem yang Diusulkan Untuk Sistem 
4.2.1.3 Data Flow Diagram Level 0 Sistem Usulan

Data Flow Diagram Level 0

sistem usulan yang terdapat pada Sistem

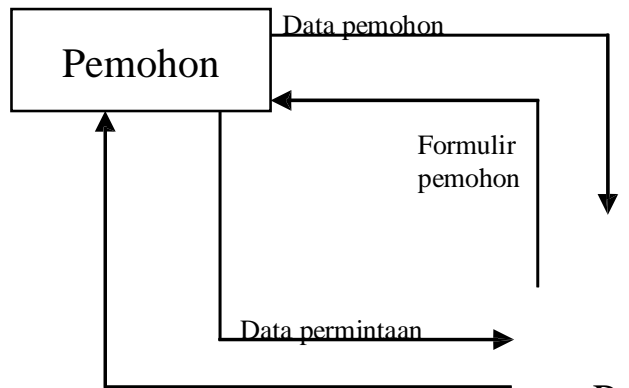

Surat kepemilikan lokasi

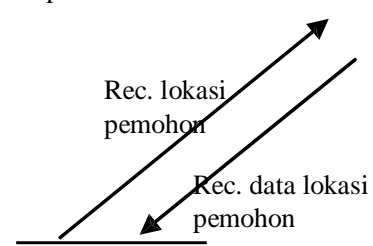

Pelaksanaan

survei

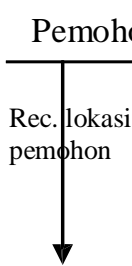

2.0

Pelaksanaan

pemasangan

lokasi
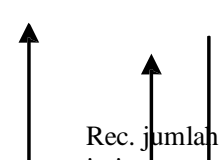
jaringan
Administrasi pasang baru indihome adalah sebagai berikut:

$$
\text { R }
$$

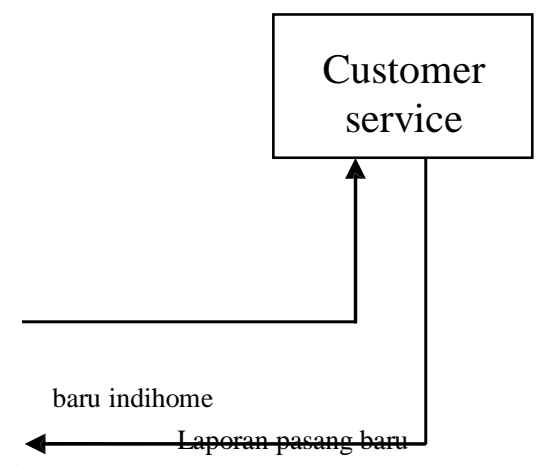

Rec. pasang baxu
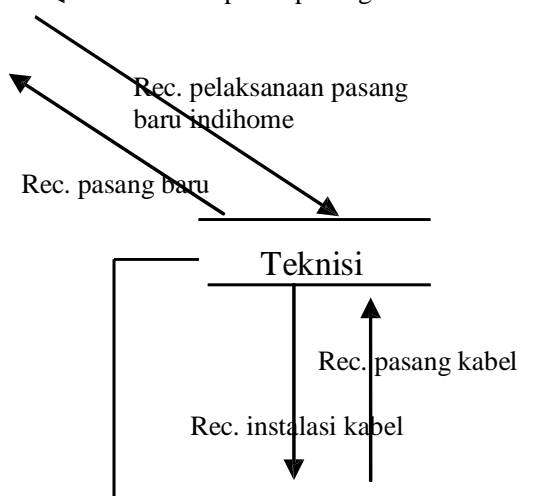

Rec. data jumldh

jaringan

Pemeriksaan indihome terpasang
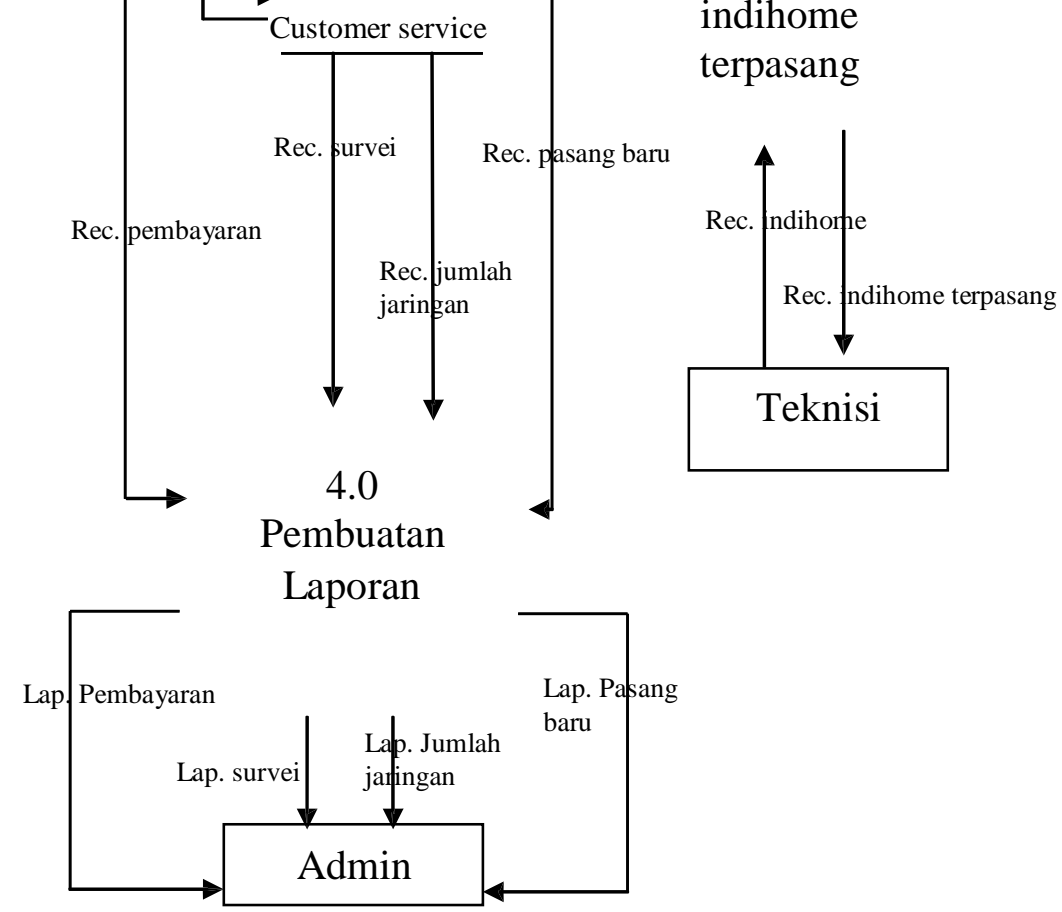

Gambar 4.6 DFD Level 0 Sistem Usulan Untuk Sistem Administrasi Pasang Baru Indihome 


\section{KESIMPULAN}

Setelah penulis melakukan penelitian ke PT. Telkom Indonesia Plasa Tanjungbalai, penulis menyimpulkan bahwa sistem usulan untuk sistem administrasi pasang baru indihome dirancang untuk mempermudah teknisi dalam melakukan pemasangan indihome, dan mempercepat pemasangan yang diharapkan oleh pemohon pasang baru Indihome tersebut.

Dengan adanya sistem usulan ini, pemohon akan dilayani oleh bagian customer service, antara lain :

1. Data-data yang diberikan pemohon akan di proses oleh bagian customer service.

2. Melakukan survei lokasi dan jumlah jaringan oleh bagian customer service.

Setelah melaksanakan langkahlangkah tersebut, maka pihak teknisi dapat melakukan pemasangan baru Indihome di PT. Telkom Indonesia Plasa Tanjungbalai.

\section{SARAN}

Adapun saran dari penelitian ini adalah sebagai berikut :

1. Sistem yang berjalan di PT. TELKOM INDONESIA Plasa Tanjungbalai kurang cepat untuk menangani permintaan pelanggan, jadi diperlukan pemberian tugas yang tepat bagi teknisi dan customer service.

2. Dari sistem yang berjalan banyak para pelanggan yang complain atas kerja para teknisi Telkom yang lambat, jadi diperlukan kecepatan teknisi dalam memperoleh laporan pemasangan dari bagian customer service.
3. Dari sistem usulan yang dibuat juga masih terdapat kekurangan yaitu tampilan sistem yang sederhana.

\section{UCAPAN TERIMA KASIH}

Dalam kesempatan ini, penulis mengucapkan terima kasih kepada :

1. Bapak Muhammad Dedi Irawan, ST., M.Kom, selaku Ketua Program Studi Teknik Informatika Universitas Asahan.

2. Bapak Helmi Fauzi Siregar, ST., M.Kom, selaku Dosen Pembimbing yang telah membimbing penulis selama mengerjakan jurnal ini.

3. Ibu Suci Rahmadaniati, selaku Customer Service yang telah membimbing saya selama melakukan kerja praktek di PT. TELKOM INDONESIA Plasa Tanjungbalai.

4. Keluarga khususnya Orangtua dan rekanrekan yang telah memberikan support. Akhir kata penulis berharap semoga jurnal ini berguna bagi pembaca khususnya mahasiswa.

\section{DAFTAR PUSTAKA}

[1] Agus Mulyanto, 2009. Sistem In.formasi Konsep \& Aplikasi. Yogyakarta: Pustaka Pelajar.

[2] A.M. Hirin, 2011. Belajar Tuntas (Dari Dasar Sampai Mahir) VB.NET 2010. Kendal : Prestasi Pustaka Publisher.

[3] Bambang Harianto, 2004. Sistem Manajemen Basis Data. Informatika, Bandung. Budi permana, 2001. Microsoft Access 2002.Elex Media Komputindo, Jakarta

[4] Budi Sutedjo, 2002. Perencanaan dan Pembangunan Sistem Informasi Sistem Informasi. Yogyakarta: Andi.

[5] Hartono Jogiyanto, 2005. Analisis dan Desain Sistem Informasi, Yogyakarta: Andi.

[6] Sondang P Siagian,1980. Filsafat administrasi.Jakarta: Gunung Agung.

[7] Suprayogi, 2011. Administrasi 
Publik: Konsep dan Perkembangan

Ilmudi Indonesia. Yogyakarta. Graha

Ilmu.

[8] Tata Sutabri, 2004. Analisa Sistem Informasi. Yogyakarta: Andi.

[9]

https://id.wikipedia.org/wiki/Data_

flow_diagram

[10]

https://www.scribd.com/doc/55468

895/Pengertian-Flowmap-dan-

Flowchart-Beserta-Simbol 